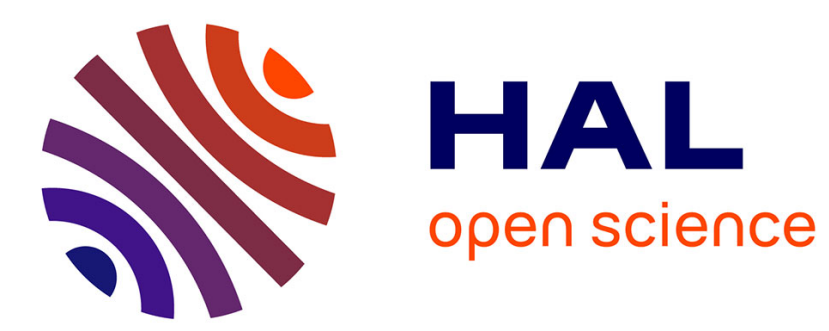

\title{
Of Milk and Blood: Innocent III and the Jews, revisited
} John Tolan

\section{To cite this version:}

John Tolan. Of Milk and Blood: Innocent III and the Jews, revisited. 2012. hal-00726485

\section{HAL Id: hal-00726485 \\ https://hal.science/hal-00726485}

Preprint submitted on 30 Aug 2012

HAL is a multi-disciplinary open access archive for the deposit and dissemination of scientific research documents, whether they are published or not. The documents may come from teaching and research institutions in France or abroad, or from public or private research centers.
L'archive ouverte pluridisciplinaire HAL, est destinée au dépôt et à la diffusion de documents scientifiques de niveau recherche, publiés ou non, émanant des établissements d'enseignement et de recherche français ou étrangers, des laboratoires publics ou privés. 


\section{Of Milk and Blood: Innocent III and the Jews, revisited ${ }^{1}$}

John TOLAN

Résumé :

Le pontificat d'Innocent III a souvent été perçu comme un tournant dans l'histoire de l'essor de l'antijudaïsme médiéval : par sa rhétorique virulente à l'encontre des juifs et par ses efforts pour limiter les contacts entre juifs et chrétiens, ce pape aurait initié une époque de tension interreligieuse accrue. Cet article examine la politique et la rhétorique d'Innocent III à travers une analyse de trois bulles envoyée en France entre 1205 et 1208. Par ces lettres, le pape cherche à maintenir la bonne hiérarchie entre chrétiens supérieurs et juifs soumis et à limiter ce que pour lui sont les fruits de l' «insolence » juive : la pratique courante de l'usure, l'emploi de serviteurs chrétiens dans les maisons juives, la vente aux Chrétiens de produits (en particulier la viande, le lait et le vin) que les juifs considèrent comme de qualité inférieure. A travers ces trois bulles nous percevons les premières expressions d'une peur qui deviendra courante au bas moyen âge : celle du contact avec les juifs (et avec leur nourriture, leur vin, leur lait), qui représenterait un danger de pollution ou d'impureté.

\section{Abstract :}

The pontificate of Innocent III has often been presented as a turning point in the history of the rise of medieval anti-Judaism: through his virulent anti-Jewish rhetoric and his attempts to restrict Christian-Jewish contact, the pope ushered in an age of growing interreligious tension. This paper reexamines the anti-Jewish policies and rhetoric of Innocent III through a close analysis of three bulls sent to France between 1205 and 1208. Through these missives, the pope seeks to enforce the proper hierarchy of Christian superiority over Jews and limit what he sees as the results of Jewish "insolence": the widespread practice of usury, the employ of Christian servants in Jewish homes, the selling to Christians of products (in particular meat, milk and wine) which Jews deem of insufficient quality for their own use. Through these three bulls we perceive the first expressions of a fear which will become widespread in the later Middle Ages: contact with Jews (their food, their wine, their milk) represents a danger of pollution or impurity.

$$
* * *
$$

Much of the past century of scholarship devoted to the history of Medieval European Jewry has attempted to trace and explain the waning of Christian tolerance and the rise of anti-Jewish prejudice and violence, as measured by a number of macabre indices: increasing

\footnotetext{
${ }^{1}$ This article is a revised version of a paper given at the conference "Thirteenth-Century France: Continuity and Change", held at the Institute for Advanced Studies at the Hebrew University, Jerusalem, February 14-17, 2011. My thanks to the Institute and in particular for the organizers of the conference, Elisheva Baumgarten and Judah Galinsky, for the invitation to participate in the conference. A revised version of this paper will be published in the conference acts (New York: Palgrave, 2013).
} 
legal restrictions, host desecration and ritual murder accusations, massacres and expulsions. Various key turning points have been suggested: the first crusade, for Bernhard Blumenkranz; the missionary preaching of the Franciscan and Dominican friars, for Jeremy Cohen; the antiTalmudic polemics of Latin authors in the twelfth century, for myself and others. But key among the culprits blamed for the rise of anti-Judaism has been one of the most powerful and charismatic popes of the Middle Ages: Innocent III. Nineteenth-century historian Heinrich Hirsch Graetz, in his monumental Geschichte der Juden, makes Innocent into the principal culprit for the ills of European Jews. ${ }^{2}$ Innocent represents "Das Papsttum in Kampfe gegen das Judentum” (p.1). „Dieser papst Innocenz III. war ein erbitterter Feind der Juden und des Judentums und hat ihnen tiefere Wunden geschlagen, als sämtliche vorangegangenen Widersacher." If more recent historians have been more sanguine in their assessment, many have agreed on the central importance of Innocent's anti-Jewish policies: Edward Synan devotes a full chapter of his The Popes and the Jews in the Middle Ages to Innocent: "For many reasons, the pontificate of Pope Innocent III has been taken as the central instance of the medieval confrontation of popes and Jews. With his reign, all the major principles have been formulated and reduced to practice; . . . the main lines had been drawn by the time this most powerful of popes died". 3 For Robert Chazan, "the pontificate of Innocent III represents both a hardening of Church policy towards the Jews and a sharpening of anti-Jewish rhetoric" $"$

Innocent indeed manages to confirm traditional papal policy towards Jews while simultaneously affirming a harder anti-Jewish line and stepping up anti-Jewish rhetoric. His issuance of the Constitutio pro Judeis is highly instructive. The Constitutio is the traditional text guaranteeing papal protection for Jews, specifically assuring that they may practice their religious rites, be free from undue pressure to convert, and have synagogues and cemeteries; violence against their persons and property is punished by excommunication. Innocent reissues the same privilege that several of his predecessors had issued, citing five of them by name. Yet he adds two brief paragraphs that change the tone considerably: first, an introduction in which he provides a theological justification for the limited and conditional

\footnotetext{
${ }^{2}$ See Heinrich Hirsch Graetz, Geschichte der Juden von den ältesten Zeiten bis auf die Gegenwart aus den Quellen neu bearbeitet, vol.7, Von Maimunis Tod (1205) bis zur Verbannung der Juden aus Spanien und Portugal (Leipzig, 1890; reprint Darmstad, 1998), p. 1-10.

${ }^{3}$ Edward Synan, The Popes and the Jews in the Middle Ages: An Intense Exploration of Judaeo-Christian relationships in the Medieval World (New York, 1965), p. 15.

${ }^{4}$ Robert Chazan, « Pope Innocent III and the Jews », in J. Moore, ed., Pope Innocent III and his World (Aldershot, 1999), 187-204.
} 
tolerance offered to Jews: "Although in many ways the disbelief of the Jews must be reproved, since nevertheless through them our own faith is truly proved, they must not be oppressed grievously by the faithful". ${ }^{5}$ And at the end of his Constitution he adds a sentence which makes these traditional guarantees precariously conditional: "We desire, however, that only those be fortified by the guard of this protection who shall have presumed no plotting for the subversion of the Christian faith". ${ }^{6}$ The implication is that some Jews plot against Christianity and for them there is no papal protection against violence.

In this article, I look at one aspect of Innocent's Jewish policy that has evoked little comment: I argue that, compared with earlier popes and legislators (lay or ecclesiastical) he shows a marked concern for questions of purity and of the dangers of pollution from contact with Jews (and for that matter, with heretics and Muslims, though that will not be our concern today). I will base my case on three letters the Pope sent to France (hence my justification for broaching this topic in a volume devoted to continuity and change in thirteenth-century France): a letter to King Philip II Augustus (16 January 1205), a mandate to the Archbishop of Sens and the bishop of Paris (15 July 1205), and a letter to the Count of Nevers (17 January 1208). In these missives Innocent expresses not only a mistrust of Jews who mock

Christianity and bear violent designs against Christians, he worries about the polluting effects of contact transmitted physically through wet nurses and through consumption of Jewish meat and wine, particularly as the latter could be used for the Eucharist.

Up until the twelfth century, bodily purity seems to have little preoccupied canon law regarding Jews. When popes, church councils and other church authorities ruled on relations between Christians and Jews, concerns of bodily purity, of "pollution" from contact with infidels, is rarely if ever a concern. Early Christian legislation sought to keep Christians out of synagogues and to prevent Jews from mocking Christian rites or symbols (for example, from burning a crucified image of Haman on Purim), but the dangers were not expressed in terms of corruption or pollution coming from physical contact with Jews. Interreligious marriage was of course prohibited, but the danger is not seen as physical contact but contumelia creatoris (insult to the creator): they are worried about blasphemy, not pollution. This is all the more striking given that in other areas physical pollution was a real issue: a number of authors address the question, for example, of whether a man who has had a wet

\footnotetext{
${ }^{5}$ Translated by Synan, The Popes and the Jews in the Middle Ages, 230.

${ }^{6}$ Translated by Synan, The Popes and the Jews in the Middle Ages, 232.
} 
dream can participate in the Eucharist. ${ }^{7}$ Jews might be seen as a theological threat to Christians, but not as a physical one.

By the end of the Middle Ages, of course, Jews were often portrayed as a real physical threat to Christians: this is seen most dramatically in the host desecration accusations and above all in the ritual murder accusations (or blood libel). Moreover, by the end of the middle ages and the early modern period, numerous texts present the physical contact with Jews (and increasingly, in the Iberian Peninsula, conversos) as dangerous and impure, a "pollution" that often involved contact with fluids: water poisoned by Jews that Christians unwittingly introduced into their bodies, or the blood, milk and semen of Jews. To cite one example among many, Vincente de Costa Mattos, in his Breva discurso contra a heretica perfidia da judaismo (Tolosa, 1696): affirms that children of Old Christians should not be suckled by "Jewish vileness because that milk, being of infected persons can only engender perverse implications."8

It is in the early thirteenth century that one sees the first signs of the emergence of this preoccupation with the "polluting" contact of Jews, and one sees it clearly in these three texts of Innocent III. Innocent is not the first to express such fears and concerns, but he is the first pope to give them wide credence and authority. We shall see that it is probably not mere coincidence that these concerns emerge concurrently with the establishment of the doctrine of the Transubstantiation, which affirmed the real, physical presence of God in the Eucharistic species. Let us first look at each of the three bulls in context.

On January $16^{\text {th }} 1205$, Innocent sent a letter to King Philip II Augustus of France. In this bull, Etsi non displiceat Domino, the pope complains of the privileged status that the king accords to Jews, which unconscionably places them above Christians. ${ }^{9}$ The Jews of the kingdom of the French have become « insolent », claims the pope. He attacks in particular the practice of money-lending, which inverses the normal power relationships between Christians and Jews: Jews abscond with the property of Christians and of the Church. Particularly unacceptable, for the pope, is the trampling of traditional jurisprudence based on oral testimony (in which Christian witnesses were accorded more authority than Jews). Here,

\footnotetext{
${ }^{7}$ Dyan Elliott, "Pollution, illusion, and masculine disarray: nocturnal emissions and the sexuality of the clergy", in Karma Lochrie, et al., eds., Constructing Medieval Sexuality (Minneapolis, 1997), 1-23.

${ }^{8}$ Quoted in David Biale, Blood and Belief : The Circulation of a Symbol between Jews and Christians (Berkeley, 2007), 115.

${ }^{9}$ For the full Latin text of the bull, with English and French translations, commentary and bibliography, see John Tolan, "Etsi non displiceat Domino", Notice n 30385 , RELMIN project, «The legal status of religious minorities in the Euro-Mediterranean world $\left(5^{\text {th }}-15^{\text {th }}\right.$ centuries $) »$, Telma Web edition, IRHT, Institut de Recherche et d'Histoire des Textes - Orléans http://www.cn-telma.fr/relmin/extrait30385/.
} 
on the contrary, more credence is given to signed documents (contracts in the Jews' possession), inverting traditional hierarchies. The letter is a bitter (if implicit) criticism of the aid and abetment that the king and his officers grant to Jewish lenders, to the detriment of Christian debtors. Beyond the question of usury, the pope lambasts what for him are other examples of Jewish "insolence": they construct new synagogues (one of which is taller than the neighboring church); they have Christian servants, in clear violation of church law; they openly mock Christians and make jest of veneration of the cross during Holy Week. The pope accuses the Jews of being accomplices to thieves and even of killing Christians: he cites the example of a student found dead in a latrine (while some historians have seen this as an accusation of ritual murder, in fact the pope does not claim that there was any ritual or liturgical dimension to this murder, which is simply seen as a product of the Jews' implacable hatred of Christians). The final lines of this bull are a barely-veiled warning to the king and an exhortation to restrain the Jews and to punish their "blasphemies".

Before analyzing this bull in greater detail, let me briefly present the two other bulls that interest us here. Innocent sent the second one, Etsi Iudeos, to the Archbishop of Sens and the Bishop of Paris on July $15^{\text {th }} 1205^{10}$. Innocent returns to the themes of Etsi non displiceat Domino, to which he refers; he also refers to similar letters which he sent to the Duke of Burgundy and the Countess of Troyes. The bull concerns the practice of Christian servants (seruientes) ${ }^{11}$ working in Jewish homes, clearly a common occurrence (well attested in Latin and Hebrew documents ${ }^{12}$ ), a point which the pope had addressed (as we have seen) in Etsi non displiceat Domino. The pope reiterates the prohibition of employment of Christian seruientes by Jews. Unlike the king, the bishop and archbishop have no legal authority over Jews. The pope thus exhorts them to use the sentence of excommunication against those Christians who have commerce with Jews who continue to employ Christian domestic servants. The pope is clearly attempting to go further than a principled condemnation, seeking to find efficacious remedies against a practice which had been frequently outlawed and remained widely practiced.

\footnotetext{
${ }^{10}$ See John Tolan, "Etsi Iudeos", Notice n 30352 , RELMIN project, «The legal status of religious minorities in the Euro-Mediterranean world $\left(5^{\text {th }}-15^{\text {th }}\right.$ centuries $) »$, Telma Web edition, IRHT, Institut de Recherche et d'Histoire des Textes - Orléans http://www.cn-telma.fr/relmin/extrait30352/.

${ }^{11}$ While in the previous bull he had spoken of Christian serui working for Jews, here he uses the term seruientes. Indeed, serui generally refers to slaves, emphasizing their non-free legal status, while seruientes refers to their functions rather than their legal status. Innocent here distinguishes between the two terms, repeatedly using the word serui to designate the servile status imposed on Jews as punishment for the killing of Christ.
}

${ }^{12}$ See E. Baumgarten, Mothers and children: Jewish family life in medieval Europe (Princeton, 2004). 
Innocent sent the third bull, Ut esset Cain, to Count Hervé IV de Donzy of Nevers on January $17,1208^{13}$. He here takes up the same themes he had already addressed in his Etsi non displiceat Domino. His main goal is to put an end to "the exaction of usury" by Jews who benefit from the complicity and help of the count and his officers. These practices have dire consequences, according to the pope: widows and orphans are stripped of their possessions; Christians are imprisoned, while the Jewish lenders who extort exorbitant usurious interest occupy castles and palaces and refuse to respond to ecclesiastical courts (concerning cases, presumably, which involve clerics and ecclesiastical goods). This situation is made possible by the complicity and support of the count, whom Innocent enjoins to cease giving his aid to these Jewish lenders. As in Etsi non displiceat Domino, Innocent here evokes, in a second section of the letter, a whole series of Jewish practices which create "scandal". First of all, Jewish butchers kill animals "according to the Jewish rite" and sell the remaining meat (all that is inedible according to kosher restrictions) to the Christians. The pope is clearly bothered by the impression that the Jews consider themselves superior to Christians to whom they sell things that they themselves judge unfit for consumption; like the undue power of the money-lenders, this inverses the hierarchy that God established between Christians and Jews. The same principle applies to Jewish women who sell milk "publicly for the nourishment of children". Is he referring to wet-nurses? Elishiva Baumgartner thinks that this is improbable, since the Hebrew documentation frequently mentions Christian wet-nurses in Jewish employ, but never the reverse. Were these women selling the milk of their domestic animals? In any case, the pope's impression, once again, is that they are selling to Christians what they judge not good enough for their families. As for wine, it is even worse, because they keep the best for themselves and sell the inferior-quality wine to the Christians; this "Jewish" wine at times is even consecrated in the Eucharist.

What do these three bulls tell us about Innocent's vision of Jews' proper place in Christian society and about how and why he thought they should be restricted to that place? I would like to focus on three elements apparent in these documents: Innocent's theology of Jewish slavery, his fear of the consequence of the "insolence" of Jews who do not accept their subservient place in Christian society, and the fears of pollution and sacrilege - notably stemming from contact between Jews and the Eucharistic species.

\section{Theology of Jewish "slavery"}

\footnotetext{
${ }^{13}$ See John Tolan, “Ut esset Cain”, Notice n 30493 , RELMIN project, «The legal status of religious minorities in the Euro-Mediterranean world $\left(5^{\text {th }}-15^{\text {th }}\right.$ centuries $) »$, Telma Web edition, IRHT, Institut de Recherche et d'Histoire des Textes - Orléans http://www.cn-telma.fr/relmin/extrait30493/.
} 
In the three bulls, Innocent justifies his exhortations to lay and ecclesiastical authorities to restrict Jewish "insolence" through the claim that Jews have submitted to slavery by rejecting and killing Christ. While Innocent is of course presenting well-worn themes, commonly found in anti-Jewish polemics and in other theological treatises, the bulls present an uncommonly clear and uncompromising legal argument founding Jewish social inferiority on theological principles.

In the three bulls, Innocent presents his action as a defense of divinely-ordained hierarchies merited by Jewish sins. In the opening words of Ut esset Cain, he compares the Jews to Cain. Just as Cain was a murderer and an untouchable, despised and rejected by humanity because he killed his brother Abel, the Jews, guilty of murdering their Lord, are vagabonds on the face of the earth; their perpetual exile punishes and recalls their crime. But just as the sign of God prevented Cain from being killed, so we must let Jews live among us. The Jews are the enemies of Christ and utter blasphemies against his name. They should be tolerated but must be kept in a position of social inferiority; they must be prevented from exercising power over Christians. Innocent affirms that they have been reduced to slavery as punishment for the crime of having killed their Lord who had come to free them. In Etsi non displiceat Domino, he develops another Old Testament prefiguration: the story in Genesis of the two sons of Abraham: Isaac, "the son of the free woman" (Sarah), who prefigures the Christians, and Ishmael, the "son of a servant" (Hagar), who represents the Jews, whose destiny is eternal servitude. Moreover, the Jews themselves implicitly accepted their status as slaves: when Pontius Pilate washed his hands of his responsibility for the death of Jesus, Jerusalem's Jews cried out, according to Matthew: "His blood is on us and on our children!" [Mt. 27:25; cited in two of the three bulls]. The Son's blood still cries out to the ears of the father, says Innocent in Etsi non displiceat Domino: thus any prince who fears divine wrath must make sure that the Jews remain subservient to Christians. This continuity of punishment is natural because of a continuity of guilt: Jews are and remain agitated by their rabid hatred of their Christian benefactors, they delight when their affairs cause divisions and conflicts among Christians, the pope affirms in Ut esset Cain.

\section{The consequence of the "insolence" of Jews who do not accept their subservient place in Christian society}

Having laid out the theological principles of Jewish servitude to Christians, Innocent is on a moral and theological high ground from which he can denounce those Jews and Christians who attempt to upset this divinely-ordained hierarchy. The fact that Jews have 
Christian servants and that they exercise undue power over Christians and over cult objects because of usurious loans inverses this divinely-decreed order and constitutes so many proofs, for the pope, of the "insolence" of the Jews. Christians who accept or even encourage such insolence are accused of aiding the Lord's enemies.

In Etsi Iudeos, Innocent affirms that even our enemies, the Saracens, cannot stand the insolent Jews and expel them from their territory. He is probably referring to the emigrations provoked by the Almohads' anti-Jewish (and anti-Christian) policies in North Africa and the Iberian Peninsula. The Jews are intolerable because of their "insolence", while they should humbly recognize their status as slaves in Christian society. Yet instead they seek to harm their Christian hosts. To illustrate this Jewish hostility, he cites a proverb which we find in other sources as early as the twelfth century, for example in the sermons of Peter of Blois ${ }^{14}$ : the Jews are "like the mouse in a pocket, like the Snake around one's loin, like the fire in one's bosom." He returns to this proverb at the end of the bull, emphasizing the animal imagery attributed to the Jews, whom he accuses of already having begun "to gnaw in the manner of a mouse, and to bite in the manner of a serpent".

Philip Augustus had all the Jews of his royal domain arrested, confiscated their property, then expelled them in 1182. His biographer, Rigord, praises the king for this expulsion, affirming that the Jews, through their usurious money-lending, had obtained half of Paris, had locked up countless Christian debtors as prisoners in Jewish homes, and had converted their Christian servants to Judaism. These things clearly justified heir expulsion, claims Rigord, for whom this is a singular proof of the king's piety. But in 1198 the king allowed the Jews to return to the royal domain and those Jews who settled there (no doubt far fewer than the number that had been expelled in 1182) seem to have specialized in moneylending. Thus, when Pope Innocent III writes this letter to the king in 1205, he catalogues (just as Rigord had) the abuses caused by Jewish usury, emphasizing that goods belonging to the Church were now in Jewish hands. This bull has been studied by historians in particular as a testimony of the practice of money lending by Jews of the Ile de France and of the tensions caused both by the subsequent debt and by the fact that royal agents participated in the coercive enforcement of the loans: particular in the arrest and imprisonment of debtors. This was one of the causes of the 1182 expulsion and it continued to create problems for Philip and his successors, some of whom took measures to reduce the risks run by debtors and to limit the role played by royal agents in collection and enforcement. These tensions

\footnotetext{
${ }^{14}$ See S. Singer, Thesaurus proverbiorum medii aevi (Berlin, 2000), p. 129-30.
} 
nevertheless continued until Philip IV the Fair, in 1306, expelled the Jews from the French kingdom (a territory much larger than the royal domain of 1182).

The situation in 1205-1208 is one of renewed tensions for the now quite small Jewish community whose principal economic activity appears to be money-lending. The resentment expressed by Rigord before 1182 is born anew, all the more so as some prominent lay and ecclesiastical authorities in the king's entourage (including Rigord himself) were not happy to see Jews readmitted in 1198. Some of them are no doubt the pope's source of information; they must have painted to him an alarming portrait of Jewish "insolence" and its dire consequences, and clearly Innocent was ready to accept their point of view with little hesitation. In the two bulls where he deals with the question of usury, Innocent paints a very dark picture indeed, insisting on the most dramatic examples of a world turned upside down: sacred vessels and other church property in hock to Jews, widows and orphans coldly disinherited, a perverted justice system in which Jewish witnesses are preferred to Christians.

Yet the symptoms of this "insolence", for the pope, go well beyond the issues of usury. He cites, as we have seen, numerous examples showing how Jews refuse to accept their subservient place in Christian society. Some involve direct challenges to Christian practice: a synagogue, taller than the neighboring church, where Jews pray so loudly that mass cannot be held next door. Some Jews, claims the pope, openly mock Christian devotion to the crucifix during holy week processions. This "insolence" is seen in commercial operations as well, where Jews sell what they consider not good enough for them (be it meat, milk or wine) to Christians, as if to their inferiors. Numerous texts indeed attest to collaboration between Jewish and Christian butchers in cities throughout Europe: as the hind legs of even properly slaughtered animals were not kosher, it made eminent sense to sell the non-kosher meat to Christians. Various Christian writers had addressed this issue before Innocent, most affirming that it was licit to buy such meat from Jews (arguing that Christian willingness to eat all that God has given us was a testimony to the superiority of the new Christian covenant over the old Jewish one); others, like Innocent, frowned on such consumption or prohibited it. ${ }^{15}$

One of the principal preoccupations of the pope in these bulls, as we have seen, is the presence of Christian servants in Jewish homes. Jews' employment of Christian servants overturns the hierarchy that must prevail, for Innocent, between the "sons of the crucifiers" and those of the Crucified. This had long been an object of legislation in both lay and canon

\footnotetext{
${ }^{15}$ See David Freidenreich, Foreigners and their Food: Constructing Otherness in Jewish, Christian, and Islamic Law (Berkeley, 2011). I thank David Freidenreich for letting me see his manuscript before publication.
} 
law: various laws of the Theodosian code prohibited Jews from owning Christian slaves (serui); these prohibitions were subsequently oft repeated ${ }^{16}$. The Pope observes that numerous Jews have Christian servants in their homes, performing domestic chores and taking care of their children. This indeed seems to be a widespread phenomenon throughout contemporary Northern European Jewry, as we see in both Latin and Hebrew sources. ${ }^{17}$ As with the collaboration between Christian and Jewish butchers, Innocent is fighting deeply entrenched and widely accepted practices, trying to paint them as scandalous in order to justify their abolishment.

\section{Transubstantiation and ritual purity}

Most of what we have examined so far is fairly standard in writing and legislation concerning Jews in the late twelfth or early thirteenth centuries: as we have seen, Innocent addresses these issues more forcefully and with greater hostility to Jews than his predecessors, but the general outlines of his Jewish policies are not new. There is one exception to this: Innocent seems to show a preoccupation with purity and with the dangers of pollution that close daily contact with Jews represent to the body of Christendom. It is perhaps no accident that the two passages in these bulls which most clearly evoke such fears both have to do with the Eucharist. It is under Innocent III's pontificate that the fourth Lateran Council (in 1215) establishes the doctrine of the Transubstantiation, according to which the bread and wine of the Eucharist are physically transformed into the flesh and blood of Christ. The doctrine provoked much debate and dissention within the Church and clearly some unease which is reflected here in passages concerning milk and wine.

We have seen that Innocent railed against the employ of Christian servants in Jewish homes. While other churchmen had worried about the spiritual dangers of such cohabitation, which could lead to apostasy, Innocent, in Etsi non displiceat Domino, intones darkly of the "abominations" that Jews inflict on their wet-nurses. He explains this more fully in Etsi Iudeos, where he denounces what he presents as a common practice: Jews oblige their Christian wet-nurses to extract some milk into the latrines for three days after they have taken communion. Did some Jews in fact oblige their wet-nurses do perform such a humiliating rite, to mark their contempt for the Eucharist? Or is the pope (or more likely one of his sources of information) making a false accusation which he knows will provoke the ire of his readers? At any case, it is quite unlikely that this was a common practice, as the pope

\footnotetext{
${ }^{16}$ For examples, see http://www.cn-telma.fr/relmin/resultats/?typeRecherche=extraits\&MOT_CLE[]=slaves .

${ }^{17}$ See Baumgarten, Mothers and Children.
} 
insinuates. Given the difficulty that families had to find wet-nurses in Medieval Europe, it is hard to believe that Jewish parents would deliberately humiliate a woman who provided nourishment to their infants. ${ }^{18}$ Moreover, Innocent's accusation presupposes, on the part of Jews, a strong disdain for their Christian servants; this does not correspond with the image we find in the Hebrew documentation: on the contrary, we find rabbis arguing about whether, for example, to give a gift to one's Christian servant during Purim ${ }^{19}$. Finally, it seems that the emergence of such rumors, and the fact that they were widely accepted (even, here, at the Lateran), has little to do with real-life Jewish practice; it is the fruit of the Christian clerics' theological preoccupations. The supposed fact that Jews oblige their wet nurses to express their milk into the latrines after they have taken communion shows (for the pope) that Jews recognize the power of the Eucharist, a power present even in the milk of these Christian women. It also suggests hostility towards the sacrament: this milk, imbued with the Divine presence, is tossed away in a filthy place. In the same way, host desecration stories will, starting in the thirteenth century, relate that Jews put hosts in latrines or on refuse heaps. ${ }^{20} \mathrm{In}$ a perverse logic, it is believed that Jews recognize Christ's presence in the consecrated host (and, here, even in the milk of women who have taken communion) and that this presence provokes their implacable, eternal and violent hatred. Here again, one is struck by the harsh language in this bull and by the Pope's tendency to spread anti-Jewish rumors: in Etsi non displiceat Domino, he accused them of complicity with thieves and with the murder of innocent Christians.

We have seen how, in Ut esset Cain, Innocent denounces the practice of Jews who make wine, keep the good wine, and sell the rest to Christians: "and with this, now and again, the sacrament of the blood of Christ is performed". Here again, the pope expresses his fears concerning the potentially sullying effects of contact between Jews and the species of the Eucharistic sacrament. In both cases, these preoccupations are to be understood in the context of contemporary debates on the doctrine of the Transubstantiation, which is subsequently adopted by the fourth Lateran Council in 1215. This preoccupation, which might seem paradoxical, highlights the hesitations and uncertainties provoked by these debates: why

\footnotetext{
${ }^{18}$ On the difficulties of finding wet-nurses in medieval Europe, see C. Klapisch-Zuber, "Parents de sang, parents de lait: La mise en nourrice a Florence (1300-1500)," Annales de démographie historique 19 (1983):33-64 ; Baumgarten, Mothers and Children.

${ }^{19}$ See Baumgarten, Mothers and Children.

${ }^{20}$ M. Rubin, Gentile Tales: The Narrative Assault on Late Medieval Jews (New Haven, 1999).
} 
should the purity (or impurity) of the wine matter if the sacrament truly transforms it into the blood of Christ, which by definition should be immune to any corruption?

\section{Conclusions:}

These three bulls confirm the portrait that a number of historians paint of Innocent as an uncompromising advocate of reducing contact between Jews and Christians. He is dealing here with common themes among Christian authors who write on Judaism and Jews, but he does so with a vehemence and an aggressiveness rare in earlier papal correspondence. These texts represent a hardening of pontifical rhetoric concerning the Jews, to whom Innocent attributes an implacable hostility towards Christianity and towards Christians, whom they mock and — given the opportunity—-kill.

I would nevertheless fall short of Heinrich Graetz's portrayal of Innocent as the chief culprit for the degeneration of Christian-Jewish relations in medieval Europe. Indeed to search for a "turning point" between an age of tolerance and one of persecution is simplistic and perhaps pointless. What we do see here, clearly, is the fear and disgust caused by everyday physical interactions between Jews and Christians, which had been and remained frequent. The fear of the corruption of the Eucharistic species by contaminating contact with Jews is present in these letters, as we have seen - and to my knowledge for the first time. While Innocent makes no accusations of host desecration per se, we see reflected in these letters some of the same concerns that will later lead to full-blown stories of host desecration - one the first and most influential of which will come some eighty years later, in 1290, in Paris. In these stories, as Miri Rubin has shown, supposed Jewish hostility towards the host serves as "proof" of the Transubstantiation. This imagined hostility confirms that Jews are the eternal and constant enemies of Christians. This poisonous idea, responsible for the loss of thousands of lives in Jewish communities throughout Europe in the fourteenth and fifteenth centuries, is not yet fully blown in Innocent's bulls. But we see the seeds from which such ideas will sprout.

This publication is part of the research project RELMIN ““"The Legal Status of Religious Minorities in the EuroMediterranean World $\left(5^{\text {th }}-15^{\text {th }}\right.$ centuries $)$ " 